\title{
Osmanlı Sarayında Bir Emanet: Uluğ Bey Sandığ
}

\section{A Trust in The Ottoman Palace: Ulugh Beg's Chest}

\section{Gülnihal Küpeli}

Dr. Öğr. Üyesi, Marmara Üniversitesi Güzel Sanatlar Fakültesi Geleneksel Türk Sanatları Bölümü Tezhip/Minyatür ASD email: gulnihalkupeli@gmail.com (DORCID ID: https://orcid.org/0000-0002-2055-0427

$\checkmark$ iThenticater

Atıf (APA 6)/To cite this article

Küpeli, G. (2020). Osmanlı sarayında bir emanet: Uluğ Bey sandığı. Atatürk Üniversitesi Güzel Sanatlar Enstitüsü Dergisi, 26(44), 49-60. doi: https://doi.org/10.35247/ataunigsed.690420

Makale Gönderim Tarihi/Received: 17/12/2019

Makale Kabul Tarihi/Accepted: $25 / 02 / 2020$

Makale Yayun Tarihi/Published: 19/03/2020

Research Article / Araştırma Makalesi

Öz

Türk dünyasının XV. yüzyılda yetiştirdiği büyük astronomi bilginlerinden Uluğ Bey (ö. 1449), pozitif bilimlere olan merakının yanı sıra dedesi Emir Timûr (ö. 1405) ve babası Şahrûh (ö. 1447) gibi sanat hamiliğini de üstlenmiştir. Sarayın, ilim erbabının toplanıp tartıștığı bir "akademi” kimliği tașıdığı bu dönemde, Semerkant ve Buhara gibi şehirler seçkin mimarî yapıtlarla donatılmıștır. Dahası, sanatkârlara gösterilen büyük ihtimam mimarî ile sınırlı kalmamış, diğer sanat dallarında da son derece önemli eserlerin ortaya çıkmasına vesile olmuştur.

Bu makalede, Uluğ Bey zamanında hazırlanıp, hâl-i hâzırda Topkapı Sarayı Müzesi'nde (Hazine 2/1846) muhafaza edilen ahşap bir sandık üzerinden söz konusu dönemin sanat algısına ve günümüze kadar tevarüs eden Türk/İslam medeniyeti içerisindeki yerine bir nebze ışı tutma amacı güdülmüştür"Uluğ Bey Sandı ğı" olarak adlandırılan bu yapıt motif, tasarım veya kompozisyon açısından tahlil edilerek ikonografik değerlendirmeye tabi tutulacak, dönemin sanat faaliyetleri bir sanatkâr gözüyle ele alınacaktır.

Anahtar kelimeler: Uluğ Bey Sandığı, Ejder Motifi, Naif Üslup, Ahșap Oymacılığı, Bezeme Sanatı

\begin{abstract}
Ulugh Beg (d. 1449) is one of the great astronomy scholars raised by the Turkish world in the 15 th century. In addition to his curiosity in positive sciences, he also undertook an art patron like his grandfather Amir Timur (d. 1405) and his father Shahrukh (d. 1447). The cities such as Samarkand and Bukhara were equipped with outstanding architectural works in that period when the supreme palace had the identity of an "academy" where the scientists gathered and debated. Moreover, the great attention to the artists was not limited to architecture, but also caused the appearance of extremely important works in other branches of art.

The aim of this article is to shed light on the art perception of the period and its place in the Turkish/Islamic civilization that has been inherited until now, through the wooden chest prepared for Ulugh Beg and preserved in the Topkapı Palace Museum $(\mathrm{H}$. 2/1846). This artwork called "Ulugh Beg's Chest" will be analyzed in terms of motif, design or composition and will be subjected to iconographic evaluation. Thus, the art activities of the period will be analyzed from the perspective of an artist.
\end{abstract}

Keywords: Ulugh Beg's Chest, Dragon Motif, Naive Style, Wood Carving, Decoration Art

\section{Giriş}

Asıl adı Muhammed Turgay ya da Mehmet Taragay olan Uluğ Bey, 1394 tarihinde Sultaniye'de dünyaya geldi. Kendisi Emir Timur'un torunlarından olup, hükümdar Muînüddin Şahruh ile soyu Çağatay asilzadelerine dayanan Gevher Şad'ın büyük oğludur. 1409'da Horasan ve Maveraünnehir eyaletlerine hakan naibi tayin edilmiş, 1446 yılında ise babası Şahruh'un ölümü üzerine tahta çıkmıştır. Saltanat yılları sırasında matematik ve astronomi ile yakından ilgilenerek astronomiye ait çeșitli tablolar hazırlayan ve Eflatun'un bilgisi ile Feridun'un haşmetini üzerinde taşıyan hükümdar vasfiyla anılan Devletşah Uluğ Bey, 55 yaşında iken 1449 yılında kendisine isyan eden oğlu Abdüllatif Mirza tarafindan öldürülmüştür (Dizer, 1989, s. 25; Barthold, 1997; Balibeyoğlu, 1997, s. 158-164).

Matematikçi, astronom, tarihçi ve şair sıfatlarını haiz Uluğ Bey, kendisini savaştan daha çok bilime adamış, zamanın Mes'ud el-Kâşî, Bursalı Kadızâde-i Rûmî ve Ali Kuşçu gibi bilginlerini sarayına toplayarak himaye etmiş, kendileriyle sürekli hasbihalde bulunmuştur (Ökten, 2002, s. 15-16; Fazlığlu, 2001, s. 98-100; Aslanapa, 1996, s.232). İslam astronomi bilginlerinden Gıyâsuddin Cemşid el-Kâşî’nin Semerkand'den babasına yazdığı mektuptaki ifadeleri bu anlamda oldukça manidardır: "Semerkand bölgesinde farklı olan şart da şu ki, ilim adamlarının en seçkinleri burada toplanmış bulunuyor. Bütün ilim dallarında ders veren müderrisler burada çok sayıda mevcut ve bunların çoğu da matematik ilimler üzerinde çalışıyor” (Sayılı, 1991, s. 78).

Semerkand'da yaptırdığı medrese ve rasathane (Valihocayev, 2003, ss. 19-39) ile çokça anılan Uluğ Bey, tarih ve edebiyatla ilgilenmekle birlikte hayatı boyunca astronomi ilminin gelişmesi için özel bir çaba sarf etmiştir. Bu arada gökyüzünün haritasını çıkarmanın yanı sıra astronomi çalışmalarının temelini teşkil eden trigonometri ilmi üzerinde de geniş araştırmalar yapmıştır. Zîc-i Ulûgî, diğer adı "Gûrgânî Takvimi”" olarak adlandırılan bu cetvel, Batlamyus ve Nasîruddin Tûsî’nin çalışmalarından sonra üçüncü büyük yıldız kataloğu olarak kabul görmüştür (Göker, 1979, s. 81-120). 


\section{Yöntem}

Araştırmada Betimsel Yöntem kullanılmıștır. Konu ile ilgili literatür taraması yapılmış olup, ilgili yazılı materyaller tek tek incelenerek analizi yapılmıştır. Araştırma konusuna kaynaklık eden Uluğ Bey Sandığı motif, tasarım veya kompozisyon açısından tahlil edilerek ikonografik bir değerlendirmeye tabi tutulmuştur.

\section{Uluğ Bey Sandığı’nın Bezeme Özellikleri}

Uluğ Bey’in bilime ve bilim adamlarını gösterdiği ilgi ve hassasiyetin bütün kültür alanlarını kuşattığını söylemek mümkündür. Sandal ağacından yapılmış olup Topkap1 Sarayı Müzesi Hazine 2/1846 numarada muhafaza edilen sandık da (Bilirgen ve Murat, 2000, s. 246-247) bu görüşün doğruluğunu ortaya koyar niteliktedir. 195 × 175 × 315 mm. ebadında, oyma tekniğinde ustalık gerektiren bir işçilikle hazırlanmış, kulpları, kilidi, menteşeleri ve çivi başları altından mamuldür (Görsel 1).

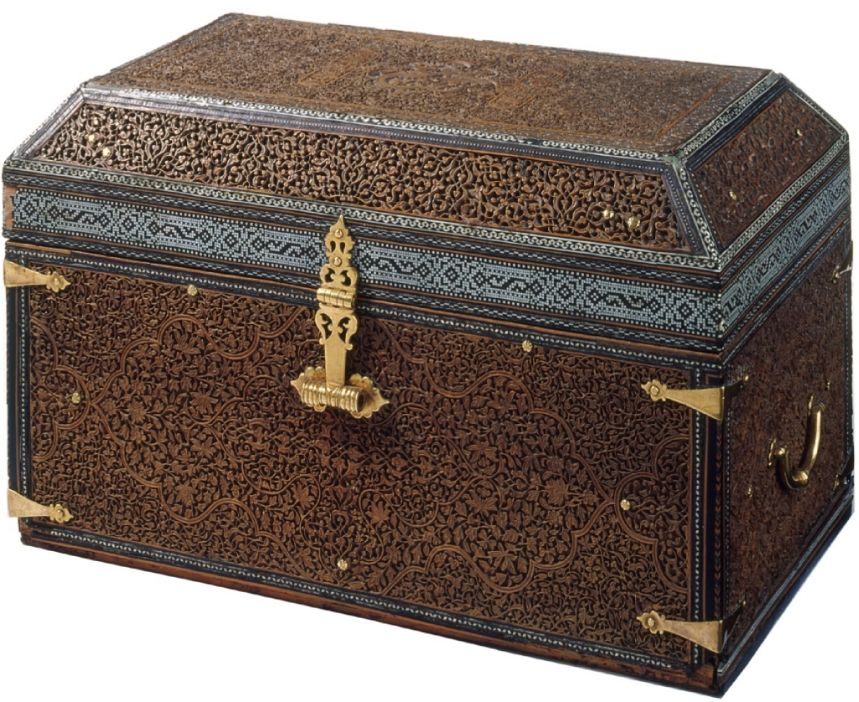

Görsel 1. TSM. Hazine 2/1846, Uluğ Bey sandığg

Saray arşivlerinde "çekmece" olarak kayıtlara geçen ancak çekmeceden ziyade bir sandık görünümü arz eden bu kutu, Timur hanedanına ait olup günümüze ulaşan objeler arasında ahşap oymacılığı ile dikkat çeken eserler arasındadır. Birbirinden müstakil oyulmuş panellerden oluşan sandığın kapak kısmında Uluğ Bey'in isim ve unvanlarını içeren iki adet kartuş bulunmaktadır. Simetrik olan kartuşlar içerisinde sülüs hat ile; "es-Sultan elÂzam ve'l- Hakan el-Ekrem Amânü'z-Zaman Uluğ Bey Gürkân” yazılıdır (Görsel 2). Bu ibare, eserin Uluğ Bey için hazırlandığını tescillemenin dışında yapım tarihi hakkında da tahmini bilgi vermektedir. Uluğ Bey için "Gürkân” unvanı ilk kez Hâfız-1 Ebrû'nun Zübdetü't-Tevârih isimli eserinde kullanılmıştır. W. Barthold'un, söz konusu eserin en erken 1417 'de yazıldığına dair görüşü kabul edilirse, (Grube, 1988, s. 178-185) sandığın 1417 ile Uluğ Bey’in ölüm tarihi olan 1449 arasında bir tarihte yapıldığı varsayılabilir.
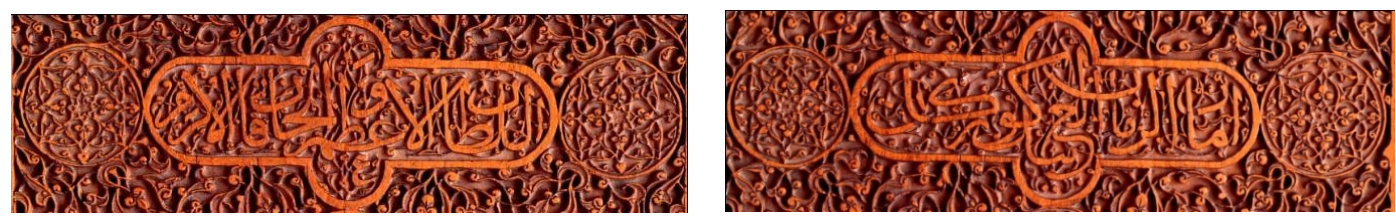

Görsel 2. Üst kapakta yer alan ve sandığın Uluğ Bey için hazırlandığını gösteren yazı

Sandıkta, ahşap ustasının veya desen nakkaşının kim olduğu hakkında herhangi bir kayıt düşülmemiştir. Fakat tarihi kaynaklardan ve günümüze kadar varlığını muhafaza etmiş bazı yapıtlardan hareketle Timurlular Dönemi'nde Semerkand bölgesinde yetenekli ahşap oymacıların bulunduğunu söylemek mümkündür. Hiç kuşkusuz söz konusu yapıtlara en iyi örneklerden biri günümüzde Hermitage Müzesi'nde muhafaza edilen Gûr-i Emir kapılarıdır (Lentz ve Lowry, 1989, s.339; Tekin, 2002, s.872-880). Tarihi kaynaklar gelince, XV. yüzyılda Timurlu sanatı ve sanatkârları hakkında bilgi veren "Arza-dâşt" (Özergin, 1976), dönemin ahşap sanatı açısından da önemli ipuçları içermektedir. Belgenin, Baysungur Mirza’ya kütüphânedeki çalışmalar hakkında bilgi vermek üzere Tebrizli Cafer Baysungurî hattat tarafindan muhtemelen 830/1427 y1lı Ramazan ayında Herat'ta kaleme alındığı düşünülmektedir. Belgede yer alan maddelerden bir kısmı kitap sanatları ile ilgiliyken bazı maddeler de eşya bezeme, sedefçilik ve ince marangozluk işleri ile alakalıdır. Buradaki kayıttan Mevlânâ Sa'deddîn’in 
dönemin ahşap ustalarından olduğunu ve Bigüm'ün sandıkçası üzerinde çalıştığını öğreniyoruz (Özergin, 1976, s. 495)

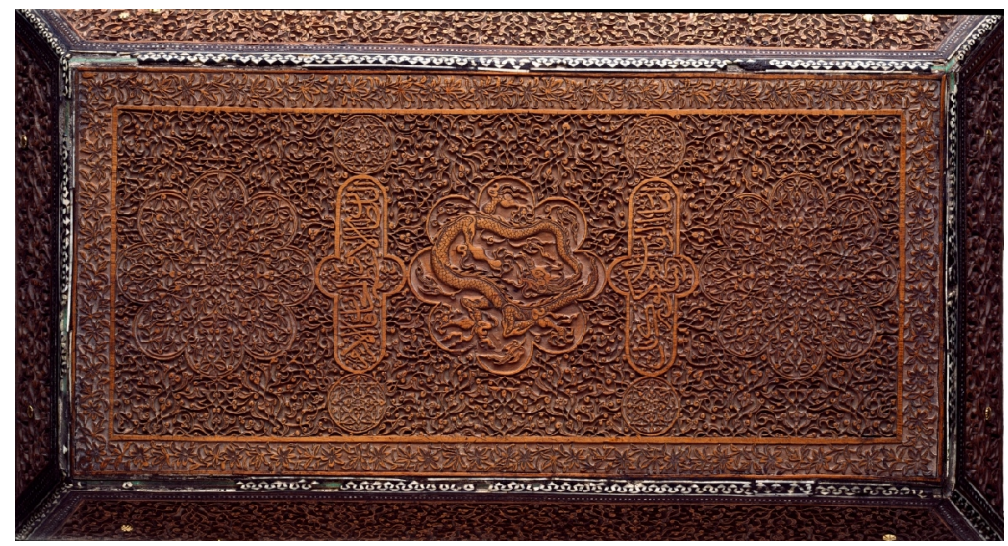

Görsel 3. Üst kapağın genel görünümü

Bigüm veya Begüm Türklerde soylu hanımlar için kullanılan genel bir unvan olup, belgede kastedilen kişinin kimliğini tam olarak açıklamıyorsa da saraydaki hanımlardan biri olduğunu göstermektedir. Arza-daşt'ın yazılış tarihi ile Uluğ Bey'in sandığı üzerinde gördüğ̈̈müz "Gürkan” ünvanını kullanış tarihlerinin örtüşmesi is, bizlere saray erbabı için çalışan usta Mevlânâ Sa'deddîn'in makalemizin konusunu oluşturan Uluğ Bey sandığını da yapmış olma ihtimalinin uzak olmadığını düşündürmektedir.

Tezhipli bir sayfa kadar yoğun desenler içeren sandık ön-arka, iki yan ve üst kapak olmak üzere beş adet büyük panel ile üst kapağ gövdeye bağlayan dört adet ince uzun ara panellerden meydana gelmektedir. Büyük panellerin her biri kendi içerisinde $1 / 4$, ara panel ise üç yöne katlanarak çoğalan ulama/raport kompozisyon düzenine göre tasarlanmıştır (Görsel 3).

Üst kapak, 1/4 simetri kompozisyon esasına göre tasarlanmış olup biri merkezde, diğerleri sağda ve solda olmak üzere üç adet yuvarlak hatlı sekizgen madalyondan ve bu madalyonları birbirine bağlayan, kitap sanatlarında "kitabeli zencirek" olarak tanımlanan dikdörtgen kartuşlardan müteşekkildir.

Kapağın tamamında kalın ipliklerle sınırlandırılan paftalar kendi içlerinde müstakil simetrik kompozisyonlar oluşturmaktadır. Sandığın her yüzeyine uygulanmış olan ve "Naif üslûp" olarak bilinen (Ettinghausen, 1977, s. 1937-1940) çalışmanın erken örnekleri, Muzafferiler Dönemi'nde (1314-1393) Fars bölgesinde hazırlanan eserler ile Celayiri hükümdarı Şeyh Üveys Dönemi'ndeki Tebriz el yazmalarının bezemelerinde görülmektedir (Tanındı,1999, s. 647-655; Soucek, 1992, s. 116-131; Tanınd1, 2009, s. 253). Bazı kaynaklarda daha erken örneklerinin izlerine de rastlanan aynı üslûbu, (Francis, 1997) daha sonra Timurî Herat (TSMK. B.282, Külliyât-1 Hâfiz-1 Ebrû), Şiraz (TSMK. H.1511, Şehnâme-i Firdevsî), Semerkand (NK.2559, Mesnevi Görsel 4) hatta Osmanlı saraylarında (TSMK. R.1726, Makâsıdü'l-Elhân; TSMK. YY. 913, Șeyh Hamdullah Mushafi; TSMK. EH.72 Şeyh Hamdullah Mushafı (Küpeli, 2007, s. 40-114-188; Küpeli, 2009, s. 321-341) XVII. yy. başlarına kadar geniş bir coğrafyaya yayılmış olarak görmek mümkündür. Uluğ Bey zamanında bu üslûpta tezhiplenen eser örnekleri TSMK. A.2831, A.2935 ve A.2111 numaralarına kayıtlı yazma eserler üzerinden incelenebilir. Yine 1446 tarihinde Ali b. İskender el-Kuhistanî hattıyla istinsah edilip, Sultan Ali el-Bâverdî tarafindan tezhip ve tasvirleri yapılan bir Hamse-i Nizami nüshasında da Uluğ Bey Dönemi'ne ait naif üslûp uygulamasına rastlanmaktadır (Tanındı, 2009, s. 254-255).

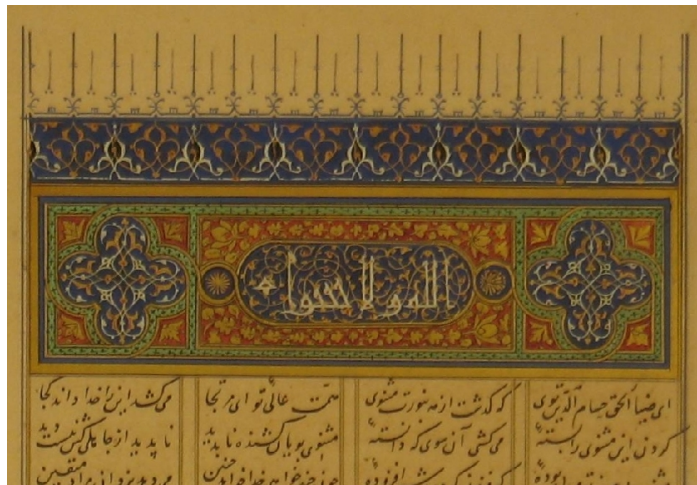

Resim 4. Mesnevi, Nuruosmaniye Küt. 2559, vr.148b. Resim 5. Şirvanşahlar Sarayı Türbesi kapı alınlı̆̆

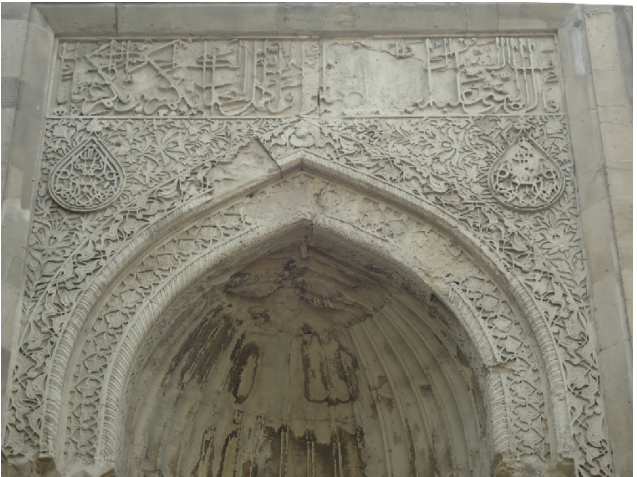

(1435-1436) İçeri Şehir, Bakü 
Bir noktadan çıkış yapıp aynı yönde hafif "S"ler çizerek devam eden, bulunduğu pafta içerisinde müstakil olarak tasarlanmış olmasından dolayı çoğunlukla serbest kompozisyon etkisi oluşturan üslûp; ahşap, metal, taş işçiliği, kâğıt gibi pek çok farklı malzeme üzerinde görülmektedir (Görsel 5). Genellikle sivri uçlu, ince uzun yapraklardan müteşekkil motifler, topraktan çıkıp, yukarı doğru filiz veren bahar dalları görüntüsündedir. Çiçeklerin bir buket halinde tasarlanmaları, 1şık-gölge veya perspektifin kullanılmadığı iki boyutlu yüzey çalışmalarına gerçekçi bir bakış açısı kazandırması ve naif üslûbun temel özelliklerini oluşturması açısından önemlidir.

Üst kapağ1 oluşturan dikdörtgen alan, naif üslûpla hazırlanmış kitap kabı veya tezhipli sayfalarda görmeye alışık olduğumuz tarzda bir pervaz ile neticelenmektedir (Görsel 6). Burada çiçekler buket tarzı bir düzenlemenin aksine sınırları belirlenmiş, ince uzun bir şerit içerisinde geniş "S"ler çizerek ilerler. Yön belirleyen dalların üzerinde sadece tekrar eden iki goncagül motifinin yer aldığı görülür.
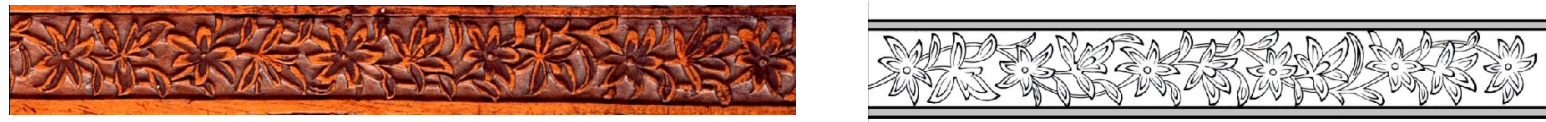

Görsel 6. Üst kapak, pervaz deseni

Üst kapağın merkezinde birbiriyle bağlantılı üç adet sekizgen madalyon yer alır. Ortadaki madalyonunun içinde tek bir ejder figürü yer alırken, diğer ikisinde rûmî ve hatayî grubu motifleri, 1/8 simetrik kompozisyon esasına göre düzenlenmiştir (Resim 3). Madalyonların dışında kalan zemin boşlukları, serbest kompozisyon disiplinine çok daha uygun olmasına rağmen yine simetriye uygun tasarlanmıştır (Görsel 7).

Madalyon tasarımın içi simetrinin en yoğun kullanıldığı alan olup, hatayî grubu ve rûmî motiflerinden oluşan iki helezon üzerine kurgulanır (Görsel 8). Dışında kalan dikdörtgen alan ise kompozisyon açısından biraz karmaşıktır. Tezyin edilecek yüzey, madalyonun merkezi esas alınarak sekiz eşit parçaya bölünmüştür. Desenin simetrik esasa göre başlayıp serbest tasarım esasına göre tamamlanmış olması izleyeni şaşırtan bir detaydır.

Sanatkârın tasarımdaki farklılığını ortaya koyduğu bu kurgu sayesinde köşeleri olan bezeme alanında yuvarlak dönüşler yapılabilmiştir. Sandığın ön, arka veya yan yüzeyleri ile üst kapağında mevcut olan 1/4, 1/8 veya 1/16 simetri kompozisyon sanatkârın sonsuzluğa açılma arzusunun somut bir ifadesi olmalıdır. Diğer bir deyimle, burada titizlikle uygulanan simetrinin, sanatkâr tarafından sadece mükemmelliği yakalamada kullanılan bir araç olmaktan çıktığını, aynı zamanda evreni somut olarak algılayış biçimini de ortaya koyduğunu ifade etmek mümkündür.
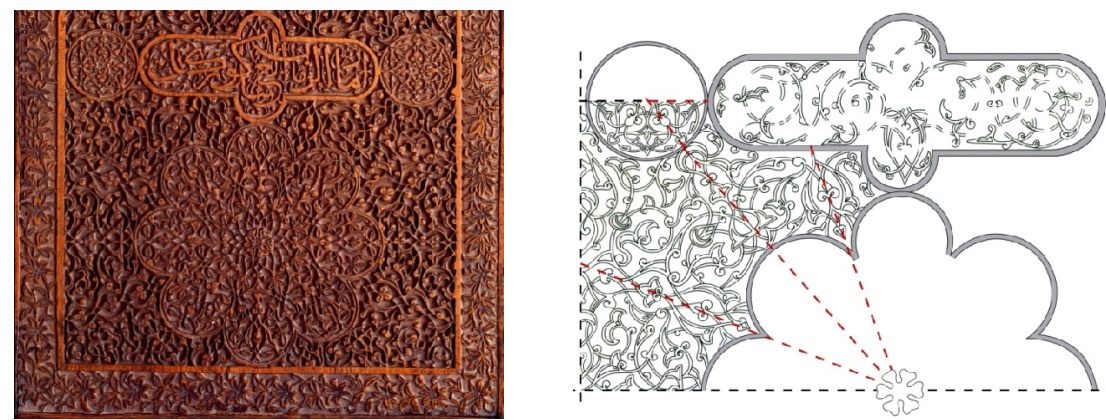

Görsel 7. Üst kapak, 1/4simetrik kompozisyon esasına göre tasarlanmış bezeme alanı

Bir düzlemin iki tarafında bulunan şekillerin ölçü ve düzen bakımından birbiri ile aynı olması durumu (tenâzur) olarak tanımlanan simetri, en temel matematiksel kavramlardan eşdeğerlilik ile sıkı ilişki içindedir. Matematikte, iki şey birbirinin aynısı ya da eşdeğeri ise buna eşit denir. Dolayısıyla simetri, şeyler arasındaki eşitliğin bir ifadesidir. Bunlar farklı nesneler veya bir nesnenin farklı parçaları da olabilir (Lederman ve Hill, 2005, s. 13). Tabiatta ise gizli ya da aşikâr olsun simetri, pek çok kez insanı yormayan bir denge unsurudur. Bu nedenledir ki insanlar simetriyi binlerce yıldır içgüdüsel olarak mükemmellikle eş değer tutmuş; simetrinin bizlere sanatsal güdülerimizi ve düşünme biçimimizi düzenleyen prensipler sunduğuna, ayrıca fiziksel dünyayı anlamada oluşturacağımız hipotezler için kaynaklık ettiğine inanmışlardır.

Gök hareketlerine ve matematiğe yakın alaka gösteren Uluğ Bey için hazırlanan sandıkta da sanatkârın, geçmişten gelen bütün bilgi birikimiyle söz konusu düşünceyi göz önünde bulundurduğu kuvvetle muhtemeldir. Sanatkâr, üç boyutlu algıladığı dünyayı iki boyutlu ifade ederken aynı zamanda formların ve biçimlerin sembolik anlatımlarını nazar-1 dikkate almıştır ki yaptığı şey aslında varoluşunu kendi anlatım biçimiyle zamanlar üstü ifade etme gayretidir. Yüzyıllar boyunca sanatkârlar, formlar, biçimler ve onlara yüklenen sembolik ifadeler değişmiş ama yöntem değişmemiştir. Çünkü bu, algılanan evreni anlatabilmenin ortak dilidir. Zira Ortaçağ’ın ruhunda köklü bir yer edinen simetri ilkesi geleneksel İslam sanatlarının da temel niteliklerindendi. Simetrinin 
genel sanat tarihi açısından önemine vurgu yapan ve Ortaçağ estetiğinin tam anlamıyla bir oran estetiği olduğuna dikkat çeken Umberto Eco'nun tabiriyle bu ilke, kutsal metinlerden beslenen ikonografik dağarcı̆̆ın gelişimini dahi belirlemekteydi: "Söz konusu dağarcı̆̆ın kaynağı, Kitabı Mukaddes, toplu ayinler ve exempla praedicandi idi, ama çoğu zaman simetriye ilişkin gereklilikler geleneğin son derece kesin olarak ilettiği bir sahneyi değiştirmeye, hatta en yaygın alışkanlıkları ve tarihsel gerçekleri ihlal etmeye götürüyordu” (Eco, 1999, s. 64).

Sandık bezemesinde ağırlıklı olarak karşımıza çıkan dörtlü veya sekizli madalyonlar, uzun kubbe formunu anımsatan, belirgin girintilere sahip dendanlar da yukarıda değindiğimiz hususu destekler bir biçimde, bilhassa XIV. yy.'a ait bezemeli Memluk yazmalarında, yine Timur mimarisinde veya yazma eserlerinde görmeye alışık olduğumuz türdendir. (TSMK. EH.1171, Müzehhib İbrahim Âmidî (Tanındı, 2009, s. 253); TSMK. H.2152, v.96b (Lentz, 1993, s. 257). Dolayısıyla Gûr-i Emir'deki uzun dilimli kubbe ile sandığın üst kapağındaki sekizli madalyon formun benzerliğini, dönemin mimari üslûbundan ahşap bezemeciliğine yapılan sanatsal iktibas olarak yorumlamak mümkündür. Burada üç boyutlu kubbenin kuşbakış1 görüntüsünün, iki boyutlu yüzeye uygulanış1 olan dörtlü veya sekizli madalyonlar ortak bir zevkin ve o dönemin sanat üslûbunun farklı alanlardaki tezahürleridir (Görsel 9).

Söz konusu uygulama dini tefekkür nazarıyla ele alındığında ise, arşı taşıdıklarına inanılan Hamele-i Arş meleklerinin dört adet olması ve bazı kozmik şemalarda köşelerde gösterilmesi faktörü, yön kavramıyla birlikte madalyon bezemenin tercih sebebine farklı bir yönden açıklık kazandıracaktır (Küpeli, 2019, s. 159).
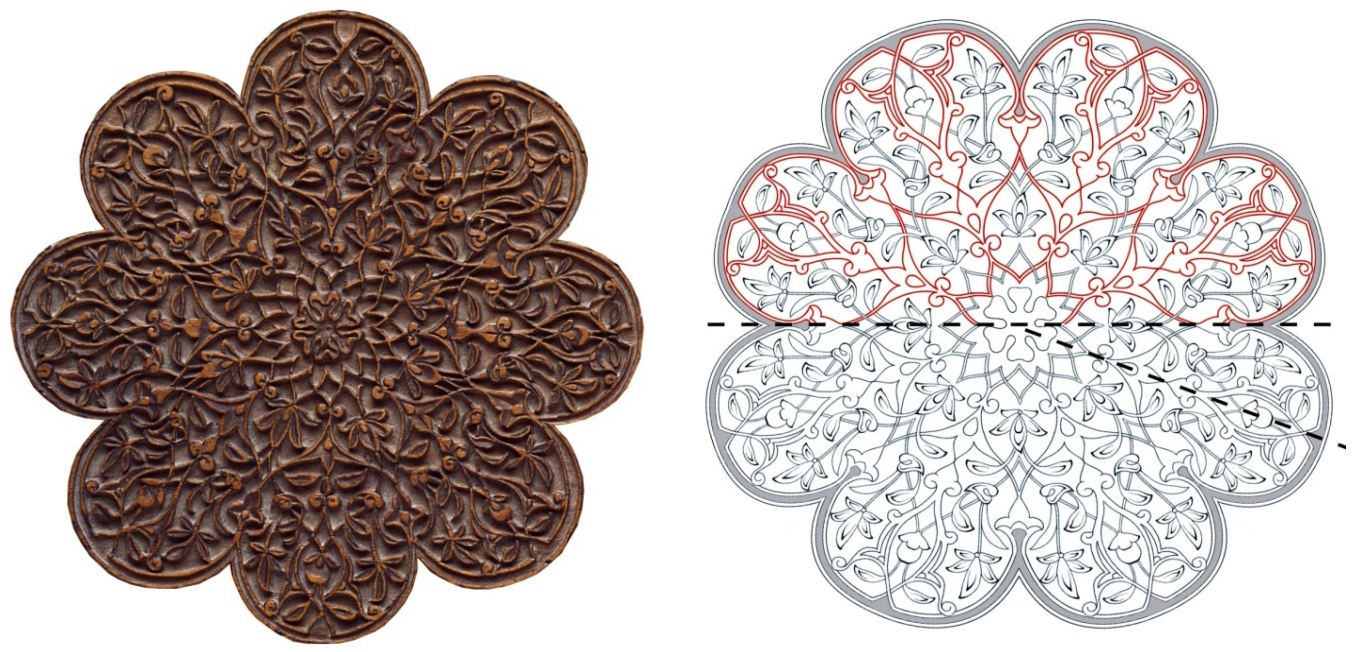

Görsel 8. Üst kapak, 1/16 simetrik kompozisyon esasına göre tasarlanmış madalyon bezeme

Uluğ Bey’in 1417-1421 yılları arasında hem Semerkand hem de Buhara'da inşa ettirdiği ünlü medreselerinde görülen dört yön tasavvuru Uluğ Bey ve zamanın bu fikre hiç de uzak olmadığını göstermektedir. Hatta simetrinin ve yön kavramının kesiştiği en iyi örneklerden sayılan bu medreselerin etkisiyle Timurlular, 14261446 yılları arasında inşa ettirdikleri dört ayrı medresenin tasarımlarında da yine dörtlü düzendeki köşe mekânlara yer vermişlerdir (Bergil, 1996, s. 77- 79).
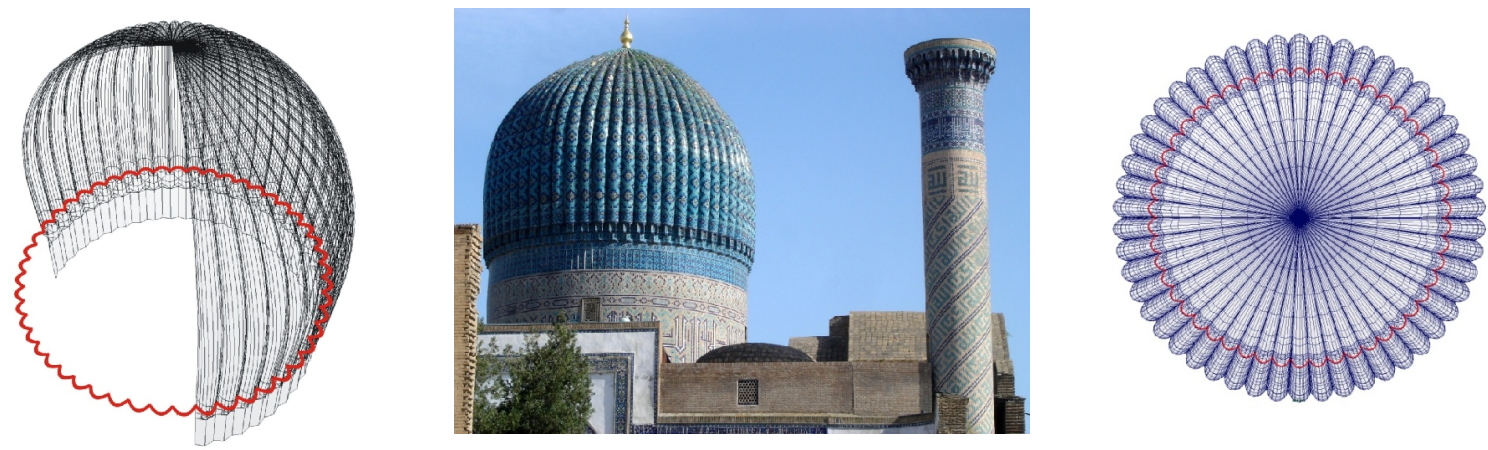

Görsel 9. Gûr-i Emir kubbesi ve kesitinin çizimi, Semerkand, 1400-1404

Üst kapağın merkezinde yer alan madalyon formun içinde bulunan ejder figürü Sandık tasarımda simetrinin kullanılmadığı tek alandır (Görsel 10). İslam sanatında efsanevi hayvan figürü grubunda karşımıza çıkan ejder, tarih boyunca bulundukları kültürlere ve coğrafyaya göre farklı isimler almıştır. Uzak Doğu ve İslam kültüründe 
farklı yorumlara konu edilen bu figüre (Öney, 1969, s.171-192; Mahir, 1993, s. 271-294; Görür, 2002, s. 55-61) Moğollar "moghur", Araplar "tannin", Çinliler "lung", İranlılar "ejderha", kadim Türkler ise "evren" adını vermiştir (İnal, 1971, s.154). Kâdim Türklerde ejder, hükümdarların avladığı ve öldürdüğü, bu şekilde kahramanlaştı̆̆ı ve kişisel gücünün yüksekliğini, mertliğini, yiğitliğini gösterir bir anlam içermektedir. Firdevsi'nin Şahnâmesi'nde Sam'ın ejderha ile savaşı ve Rüstem'in ejderhayı öldürmesi gibi konular uzun uzun anlatılmaktadır. Burada ejderha bir yönüyle yiğitliğin diğer yönüyle ise kötülüğün sembolik ifadesidir (Çoruhlu, 1995, s. 61). Örneğin Kaşgarlı Mahmud Divan-ı Lûgat-it Türk adlı eserinde ejderhanın kötülük sembolü olduğu kadar yiğitlik ve güç sembolü olduğundan da bahsetmektedir (Kaşgarlı Mahmud,1986, s. 227-228). Ejderha ile mücadele kötülükle mücadeleyi sembolize ettiği için, adil ve iyi bir yönetimle kötülük ortadan kalkacağından, zaman zaman hükümdarların sembolü olarak kullanılmıștır. Yine eski kültürlerde "ejdarha öldürmek" bazen sadece kahramanlık belirtisi olmaktan öte ebedileşmenin bir yolu olarak da görülmüştür (Yöndemli, 2006, s. $153)$.
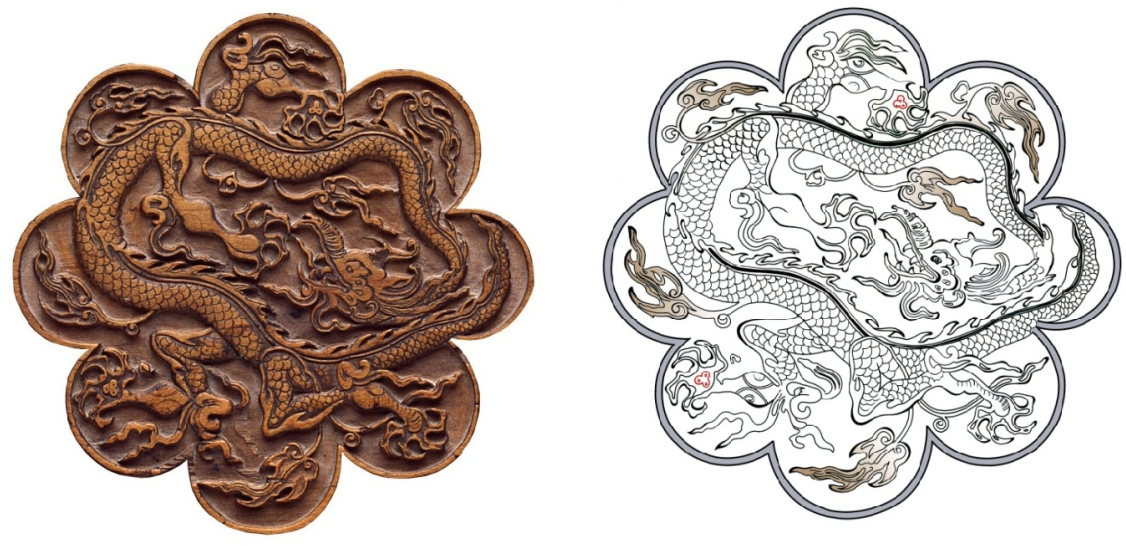

Görsel 10. Üst kapak, merkez madalyon içerisindeki ejder figürü ve çizimi

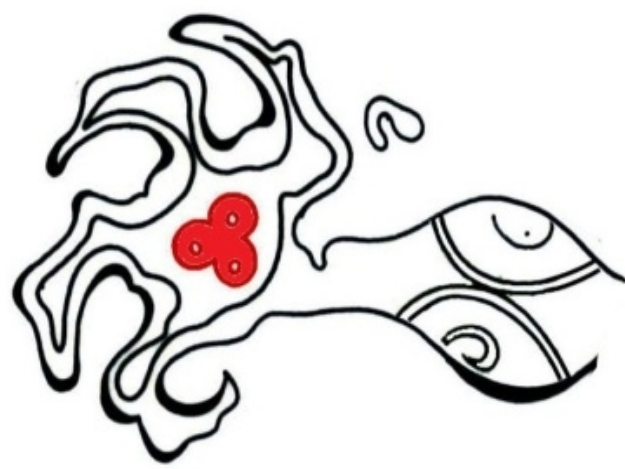

Görsel 11. Ejder figürünün ayağında yer alan çintemani motifi

Türk sanatı içerisinde ejderin temelde iki çeşit sembolizm ile ifade edilmesi, söz konusu simgenin içerdiği gök ve yer-su tasavvurlarıyla alakalı olmalıdır. Bu ise mutlak zıtlığı değil, birbirini tamamlayan bir mütekabiliyeti ifade etmektedir. Karanlık yer ve parlak gök (Yin-Yang) sembolizmi Türklerdeki temel unsurlardandır ve birbirine zıt gibi görünen bu tasavvurlar aslında birbirlerini tamamlamaktadır (Çoruhlu, 1995, s.43-45). Türklerde ve Çinlilerde müşterek bir tasavvurla ifade edilen karanlık yer ejderi ait olduğu durumdan dolayı toprak veya su içinde yaşayan hayvanlara benzetilmiştir. Yer ejderi Çin mitolojisinde "Li" diye adlandırılan boynuzsuz ejderdir. Denizde yaşayan bu yaratık derinliklerin hâkimi olup, aynı zamanda bilgin ve araştırmacıların da simgesidir. Türklerde fil başlı, sarı renkli ejder yeryüzünün sembolü iken, Çin tasavvurunda dört pençeli ejder dünyevi gücün sembolü olarak ele alınmaktadır (Çoruhlu, 1995, s.45-47). 

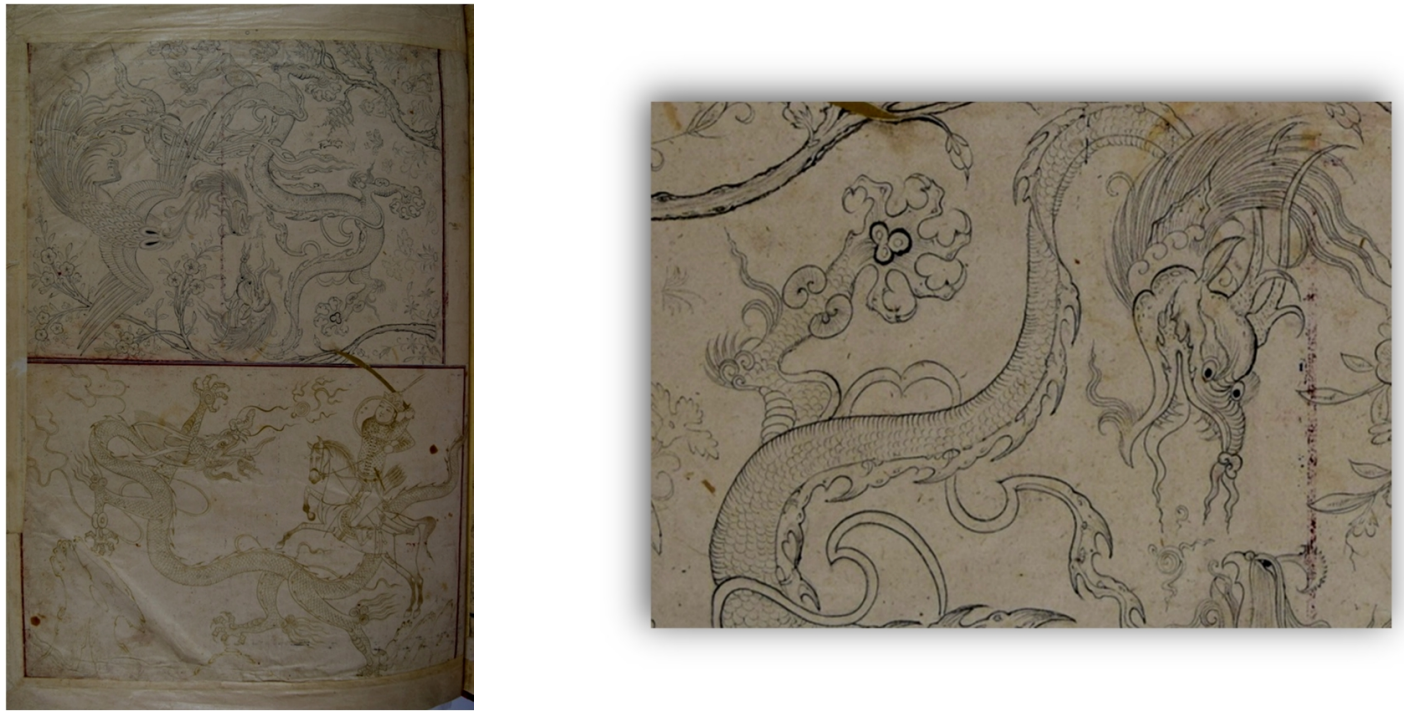

Görsel 12. TSMK. H.2152, vr. 97b, simurg ile mücadele eden ejder figürü ve ayağındaki çintemani detay1

Orta Asya ve Çin sembolizmindeki kanatlı, boynuzlu, pullu ve ayaklı ejder ise parlak gök ejderdir. Örneğin, dört ana yönü temsilen dört renk ve hayvan sembolizmi kullanan Türklerde doğunun sembolü olan "Kök Luu" (Esin, 1969, s. 163). Uygurlarda pullu ve dört ayaklı bir "makara” (timsah) olarak tasvir edilir ve Kök Luu'nun baharda uçma vakti geldiğinde, gök ejderi unsuru olan boynuzlara, pullara ve kanatlara sahip olur (Esin, 1969, s. 164). Gökyüzüne çıkar ve uçmaya başlar. Yıldırım ve rüzgârın rolünü üstlenerek yağmurun yağmasını sağlar. Böylece Türk mitolojisinde gök ejderi aynı zamanda su, bolluk, bereket ve yeniden doğuşun timsali olarak, göğe yükselme teması ile birlikte gücün ve kuvvetin uğurlu sembolü haline dönüşür (Çoruhlu, 1995, s. 48-49).

Yukarıda değinilen ikonografik bilgilere istinaden, Uluğ Bey sandığındaki figürün gök ejderini simgelediği kuvvetle muhtemel kabul edilebilir. Nitekim boynuzları, pulları ve dört ayağının varlığı, yine buluta benzer kıvrımlarla çevrelenmiş olması bu görüşü destekler niteliktedir. Bu arada 14. yy. Şiraz'ında yapılıp, Behram Gûr'un ejder ile mücadelesinin tasvir edildiği bir minyatürdeki (TSMK. H.1511, vr. 203, Şiraz, 1370-71) ejder ile sandıktaki ejderin form itibari ile benzerliğine de değinmek gerekir. Zira bu bir taraftan ejder sembolü için ifade edilen kahramanlık ve alplik tasavvurunu geçerli kılmakta; diğer taraftan ise küçük kafası, büklümlü formu ve gagaya benzer ince uzun burnu dolayısıyla sandık kapağındaki ejderin Şiraz atölyelerinin çizim üslûbunu anımsattığını ortaya koymaktadır (Grube, 1988, s. 178-185). Bunun yanı sıra sandıktaki ejderin iki ayağı üzerinde resmedilen "şâhî benek ya da benek nakşı" sembolü, ejderin kullanılışındaki eski göçebe Türk geleneğinin devamı niteliğinde güç, kuvvet ve iktidar manasını (Doğanay, 2004, s. 193-218) kuvvetlendirmektedir. İktidar simgesi olmasının yanı sıra Reşideddin'in Oğuzname'sinde ejderin bulunduğu yere adalet getirdiğine ya da şifa dağıtıcılığına dair bazı rivayetler de mevcuttur. Örneğin, Buğra Han ile oğlu Qorı Han arasında geçen bir hadisede "Div Qayası" adında yüksek bir dağın eteklerinde bulunun üç ulu ağaç ve bu ağaçların her birinin altındaki ikişer "Mavi Ejder”den bahsedilmektedir. Rivayete göre bir suç ile itham edilen insanlar vücutlarında yaralar açılarak mavi ejderin yanına getirilirdi. İtham olunan kişi suçlu ise ejderler tarafından yenilerek cezalandırılır, masum ise yaraları yine aynı ejderler tarafından yalanarak iyileştirilirdi (Togan, 1982, s. 65-66; Ekiz, 2011, s. 42).

Aslı Sanskritçe olup 10. Yüzyılda Uygur Türkçesine çevrilen “Iyi ve Kötü Prens Öyküsü” isimli eserde (Orkun, 1940) iyi prensin tüm varlıklara yarar sağlayacak bir "çintemani” mücevherinin peşinde olduğundan bahsedilir. Bu mücevher "Ejderhalar Hanı"nın elindedir ve iyi prens mücevhere ulaşıp onu almak için çeşitli merhalelerden geçecektir (Russell, 2011, s. 37). Buradan hareketle Uluğ Bey sandığının kapağında yer alan ejder figürünün çevresindekileri iyiliklere ulaştırmak isteyen bir hükümdarın iktidarını simgelediği düşünülebilir. Ejderin iki avucunda resmedilen ve Timûrî Dönem sanatında kullanılan bazı motifler gibi eski Çin ve Uygur kültürünün izlerini taşıyan çintemani motifi de bu yorumu kuvvetlendirmektedir (Resim 11). Sandığın bir mücevher kutusu olması çintemani motifini daha da anlamlı kılarken, pençesinde bu motife yer verilen benzer ejderha resmini Topkapı Sarayı Müzesi'nde muhafaza edilen H. 2152 numaralı albüm çizimlerinde görüyoruz. Ejder ile Simurg'un mücadelesini yansıtan söz konusu çizimin altına "Kâr-1 Hasan-1 Şîrâẑ̂” imzası düşülmüştür (vr. 97b) (Görsel 12). Yine dört tırnaklı olup, pençesinde çintemani motifine yer verilen benzer ejder motiflerine XIII. Yüzyılın sonlarına tarihlenen Taht-1 Süleyman objelerinde de rastlamak mümkündür (Komaroff, 2002, ss.175176; Masuya, 2002, s. 95; Kuehn, 2011, s. 216, res. 186a-b). 

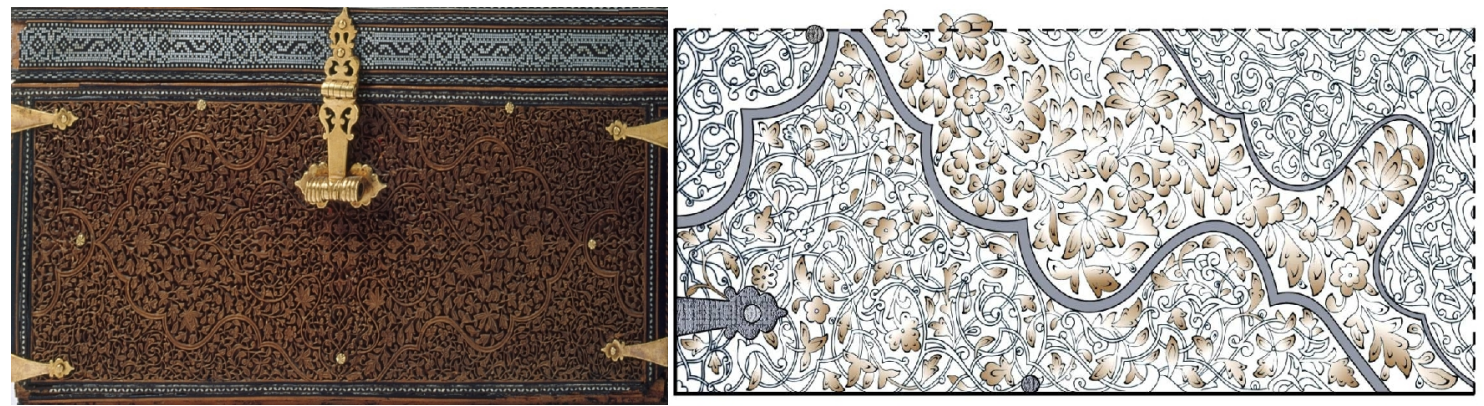

Görsel 13. Sandığın ön yüzü ve $1 / 4$ desen analizi

Sandığın ön ve arka yüzünde iç içe yerleştirilmiş iki adet dendanlı şemse formu bulunmaktadır. Paftalar ardışık olarak rûmî ve hatayî grubu motifleri ile tasarlanmıştır. Her iki şemse formu 1/4 kompozisyon esasına göre düzenlenmiş, iç kısımdaki şemsenin uzun kenarları ise hûrde salbek formu ile neticelendirilmiştir. Bu haliyle bir şemse salbekten müteşekkil kitap kabı görüntüsündedir (Görsel 13). Tasarım içten dışa doğru farklı motif grupları ile oluşturulmuştur.
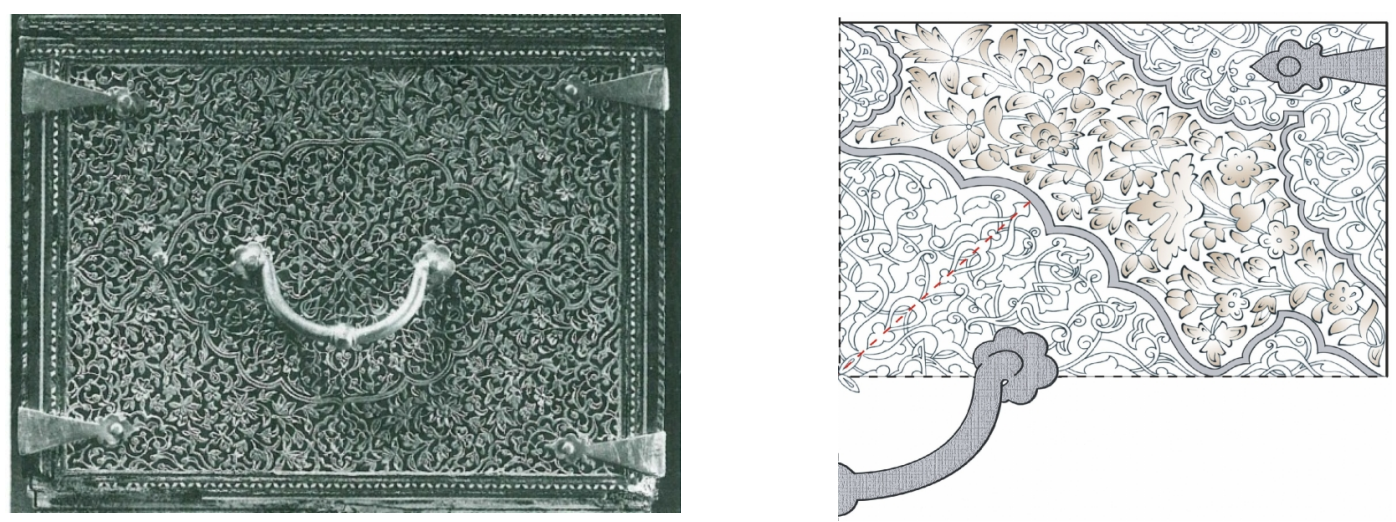

Görsel 14.Sandığın yan yüzü ve $1 / 4$ desen analizi

Merkezde bulunan daha küçük ebatlı şemse ve salbek formunda sadece rûmî motifleri kullanılırken, onun dışında yer alan ikinci şemse, hatayî grubu motifleri ile tasarlanmıştır. Geri kalan tezyini alana ise her iki motif grubunun bir arada uygulandığı alandır. Ön kısmın uzun kenarlarında yarısı görülen dörtlü madalyon formu yine rûmî motifi ile tezyin edilmiştir.

Sandığın yan panellerine uygulanan bezeme, tıpkı kitap kablarında olduğu gibi şemse, dört yöne bakan salbek ve köşebentlerden müteşekkildir. Ön paneldekine benzer biçimde burada da motif grupları ipliklerle ayrılan paftalar içerisinde ayrı ayrı tasarlanmıştır (Görsel 14). Desen hazırlanırken yanlarda bulunan altın kulplar düşünülerek çizilmiş olmalıdır ki bu ayrıntılar desenin akışında herhangi bir sorun oluşturmamaktadır.

Sandığın estetik görünümünü kuvvetlendiren eğimli paneller eserin tamamında olduğu gibi simetrik kompozisyon esasına göredir. İnce uzun dikdörtgenden oluşan bölüm rûmi motifleri ile üç yöne katlanabilen ulama/raport kompozisyon tarzındadır. Diğer parçalarla birleşmesini ise yine kurdele kurtçuk desenli ince pervazlar sağlar (Görsel 15).

Sandık kapağının ön ve yan yüzleri, kitap sanatlarında kurdele kurtçuk adı verilen, ince kakma fildişi bordür ile birbirine bağlanmış; ön-arka ve yan paneller üst kapağa yine fildişi bordürle birleştirilmiştir. Bordürlerde sivri uçları olan iki adet sekizgen formun, yine uçları sivri ince uzun kitabelerle birbirine eklenerek çoğaltıldığ görülmektedir. Açılan kitabelerin içerisinde ise, iki ucu baklava dilimi formu ile neticelendirilen ve dönüşümlü olarak biri aşağı diğeri yukarı bakan uzun "S" ler yer almaktadır (Görsel 16).
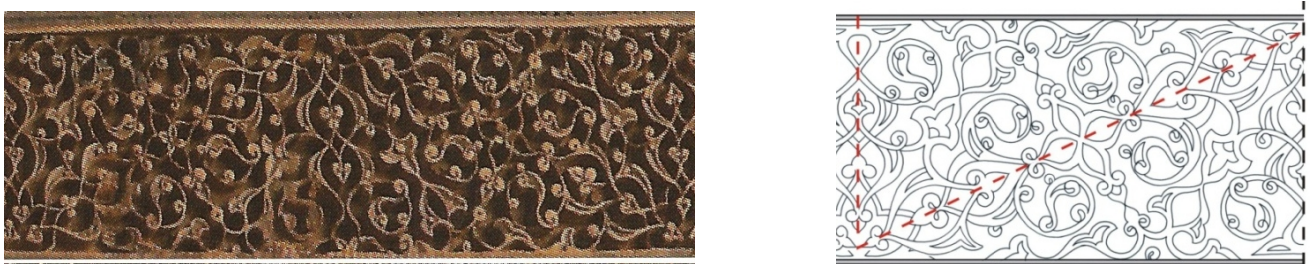

Resim 15. Üst kapağın eğimli parçası ve deseni 
Sandığın fildişi kakma desen uygulaması dönemin en çok kullanılan bezeme şekillerindendir. Semerkand'daki Gûr-i Emir'in diş cephesinde görülen mozaik süsleme buna en güzel örnektir (Beksaç, 1996, s.197-199). Ayrıca Osmanlı coğrafyasında, 1472 yılında Fatih Sultan Mehmet tarafindan Topkapı Sarayı'nda yaptırılan ilk bina olma özelliğini taşıyan Çinili Köşk'ün kapısının sağ ve sol duvar çinilerinde de aynı tarz bezemeye rastlanır (Görsel 17) Çinili Köşk mozaikleri ve sandıktaki mozaği yapan ustasının kimliği bilinmemekle birlikte, desenleri arasındaki neredeyse birebir benzerlik, Uluğ Bey’in azad ettiği Timurî sanatkârlardan ya da onların yetiştirdiklerinden olma ihtimalini yüksek kılmaktadır. Nitekim Uluğ Bey’in 1411 senesinde verdiği fermanla önceleri Semerkand'den ayrılmaları yasak olan sanatkârlara azatlık verilmiş ve bununla da Timurî üslûbu temsil eden sanat adamlarının İslam dünyasının diğer bölgelerine gidebilmeleri mümkün olmuştur (Lentz ve Lowry, 1989 , s. 63)
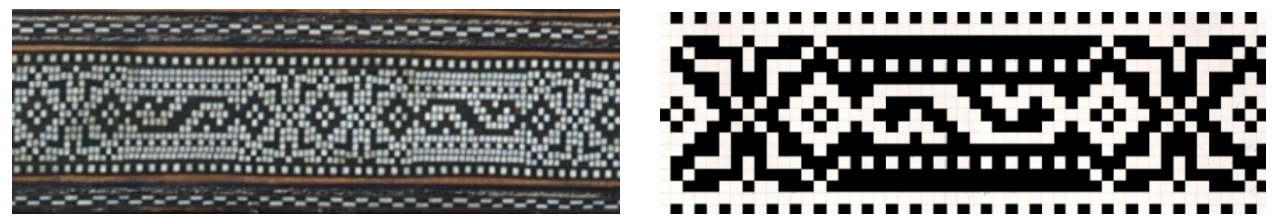

Görsel 16. Sandığın fildişi kakma bordürü ve desen ayrıntısı

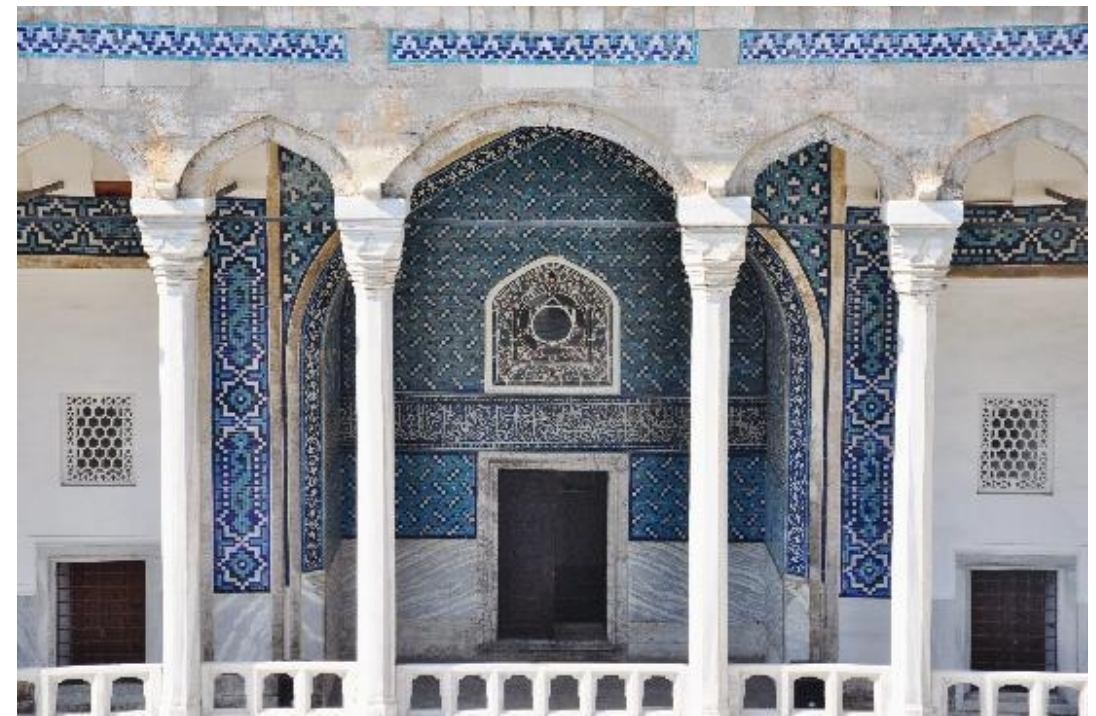

Görsel 17. İstanbul, Çinili köşk bordürleri

İç kısmında küçük bir göz bulunan sandığın, bu göz dâhil bütün iç yüzeyi, o döneme ait olduğu söylenen ipek kumaş ile kaplanmıştır (Bilirgen, t.y., s. 76-84). Kırmızı renkli kumaşın üzerinde gümüş iplik ile dokunan hataŷ̂ grubu motifleri dört yöne katlanarak çoğaltılan ulama/raport tarzında tezyin edilmiştir. Katlanan en küçük birim ise kendi içerinde penç motifi merkezli olmak üzere çark-1 felek simetrik kompozisyon esasına göredir (Görsel 18). Kitap sanatlarındaki çift tahrir tekniğinin uygulamasını anımsatan kumaş deseninden, dönem sanatkârlarının ustalığı bir kez daha anlaşılmaktadır.
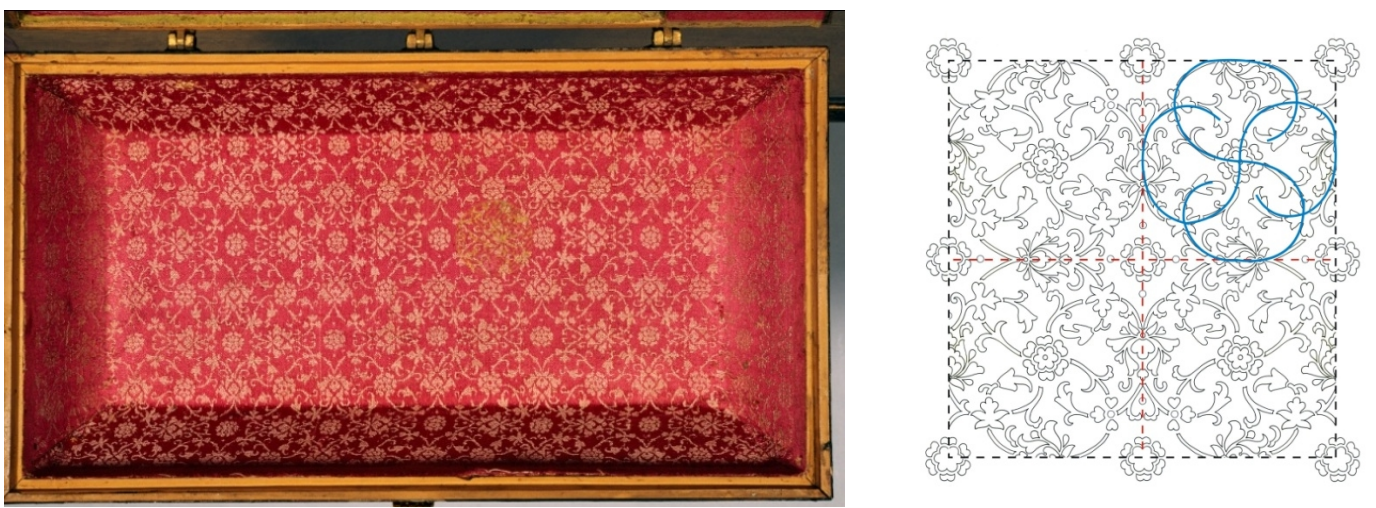

Görsel 18. Sandığın içi ve ulama/raport tarzındaki ipek kumaşın desen analizi 


\section{Sonuç}

Netice olarak öncelikle şunu belirtelim ki, tıpkı Hermitage müzesinde sergilenen Gûr-i Emir kapıları gibi, Topkapı Saray Müzesi’nde muhafaza edilen Uluğ Bey sandığı da XV. yy.'da Semerkand ve çevresindeki kültür havzalarında oldukça ehil ahşap oyma ustaları bulunduğunun somut kanıtıdır.

Sandığın genel itibariyle tezyinatı 1/4 simetrik kompozisyon şeklindedir. Desen Timurî saraylarında görülen kitap kabı ya da zahriye sayfasındaki gibi oldukça yoğundur. XIV. yy.'da geniş bir coğrafyada hâkim olan naif üslûp ince işçiliği ile hemen göze çarpar. Dört unsur kavramından beslendiğini düşündüğümüz dörtlü ve sekizli madalyonlar ve ejder figürü ile pekiştirilen iktidar imgesi bezemenin ikonografik yapısına gönderme yapar. Bir diğer vurgu; dört parmaklı ejderin iki ayağındaki çintemani ile tebası için her türlü zorluğa göğüs geren adil ve iyi yürekli yöneticiye yapılan vurgudur. Detaylar, incelikle tasarlanmış ve işlenmiştir. Sandık üzerinde, firçanın kâğıt zeminde gösterdiği incelik kadar hassas ahşap işçilik görülmektedir. Bütün yüzeylerin simetrik kompozisyon anlayışı ile tezyin edilmesi; yine gerek ejder ikonografisini gerekse de yoğun simetri tasarımları ihtiva eden sekizgen madalyonlar, dönemin dinî ve iktidar tasavvurlardan beslenen sanat algısının birer tezahürüdürler.

Tabiî olarak her türlü sanatsal yapıt daha önceden anlamla donatılmış ve düzenlenmiş bir dünyayla, siyasi ve kültürel ilişkiler ağı içerisinde kavranmakta, dolayısıyla da bir sanatkârın eserinde ortaya çıkan en önemli estetik değer onun sahip olduğu bilinçten kaynaklanmaktadır. Bu bakış açısıyla Uluğ Bey sandığı; sultanın günümüze gelen çok az kullanım eşyasından biri olması hasebiyle hem de motif kullanımı, tasarım inceliği ve ifade ettiği sembolik anlamlar ile dönemin estetik bilincini, çeşitli hanedanlar arasındaki kültürel etkileşimi/devamlılığ ve Ortaçağ'a damgasını vurmuş Türk/İslam medeniyetinin ihtişamını gözler önüne seren özgün sanat yapitlarındandir.

\section{Kaynakça}

Aslanapa, O. (1996). Türk Cumhuriyetleri Mimarlık Abideleri N.7. Ankara: Türksoy Yayınları.

Balibeyoğlu, L. (1997). Büyük Türk astronomu Uluğ Bey. Bilig, 6, 158-164.

Barthold, W. (1997). Uluğ Beg ve zamanı (İ. Aka, Çev.). Ankara: Türk Tarih Kurumu.

Beksaç, E. (1996). Gûr-1 Emîr. İslam Ansiklopedisi 14.Cilt (s.197-199) içinde. İstanbul: Türkiye Diyanet Vakfi. Erişim adresi: https://islamansiklopedisi.org.tr/gur-i-emir

Bergil, M. S. (1996). Uluğ Bey’in medreselerindeki dört yönlü köşe mekânlarının geçmişimizdeki yeri. S. Boybeyi (Ed.), Uluğ Bey ve Çevresi Uluslararası Sempozyumu Bildirileri (s. 67-88) içinde. Ankara: Atatürk Kültür Dil ve Tarih Yüksek Kurumu.

Bilirgen, E. (t.y). Saray koleksiyonundan çekmece ve kutular. Antik Dekor, 85, 76-84.

Bilirgen, E., \& Murat, S. (2000). Imparatorluk hazinesi. Topkapı sarayı (s. 198-253) içinde. İstanbul: Akbank Yayınları.

Çoruhlu, Y. (1995). Türk resim sanatında hayvan sembolizmi. İstanbul: Seyran Kitap.

Dizer, M. (1989). Uluğ bey. Ankara: Kültür Bakanlığı Yayınları.

Doğanay, A. (2004). Türk sanatında pelengi ve şahi benek ya da çintemani yanılgısı. Divan, 2(17), 193-218.

Eco, U. (1999). Ortaçă̆ estetiğinde sanat ve güzellik (K. Atakay, Çev.). İstanbul: Can Yayınları.

Ekiz, M. (2011). Niğde'deki Hıristiyan Türk kiliselerinde yer alan ejder figürleri: İkonografik açıdan bir bakış. Sanat Tarihi Dergisi, 1(20), 39-62.

Esin, E. (1969). Selçuklu sanatı evren tasvirinin türk ikonografisindeki menşe'leri. Selçuklu Araştırmaları Dergisi, 1, 161-182.

Ettinghausen, R. (1977). Manuscript illumination. A. U. Pope ve P. Ackerman (Ed.), A survey of art from prehistoric times to the present (3.Cilt) (s. 1936-1974) içinde. Tahran: Soroush Press.

Fazlıŏlu, İ. (2001). Kadıâde-i Rûmî. Íslam ansiklopedisi (24.Cilt) (s. 98-100) içinde. İstanbul: Türkiye Diyanet Vakfi. Erişim adresi : https://islamansiklopedisi.org.tr/kadizade-i-rumi

Göker, L. (1979). Uluğ bey: Rasathanesi ve medresesi. Ankara: Elif Matbaacılık.

Görür, M. (2002). Beylikler dönemi mimarisinde figürlü süsleme. Türkler (8.Cilt) (s.55-61) içinde. Ankara: Yeni Türkiye Yayınları. 
Grube, E. J. (1988). Notes on the decorative arts of the Timurid period II. E. J. Grube ve E. G. Sims (Ed.), Islamic art: An annual dedicated to the art and culture of the Muslim world (s. 175-208) içinde. New York: The Islamic Art Foundation.

İnal, G. (1971). Susuz han'daki ejderli kabartmanın Asya kültür çevresi içindeki yeri. Journal of Arts, 153-184.

Kaşgarlı Mahmud (1986). Divan-ı Lûgati't-Türk tercümesi (3.Cilt) (B. Atalay, Çev.). Ankara: Türk Dil Kurumu.

Küpeli G. (2007). II. Bayezid Dönemi Tezhip Sanatı ( Sanatta Yeterlik Tezi). YÖK veri tabanından erişildi (Tez No. 261440).

Küpeli, G. (2009). Tezhip sanatında yenilik arayışları: II. Bâyezid dönemi (1481-1512). A. R. Özcan (Ed.), Hat ve tezhip Sanatı (s. 321-341) içinde. Ankara: Kültür Bakanlığı Yayınları.

Küpeli, G. (2019). Notes on the formation of hilya design: Calligraphy-illumination interaction and numeral symbolism. Kafkas Üniversitesi Sosyal Bilimler Enstitüsü Dergisi, 2(Fuad Sezgin Özel Sayıs1), 155-176. doi: https://doi.org/10.9775/kausbed.2019.024

Lederman, L. M., \& Hill, C. T. (2005). Simetri ve Evrenin görkemli güzelliğini anlamak. B. Akalın (Çev.). İstanbul: Güncel Yayıncılık.

Lentz, T. W., \& Lowry, G. D. (1989). Timur and the princely vision: Persian art and culture in the Fifteenth Century. Los Angles: Los Angles Country Museum Of Art.

Lentz, T. W. (1993). Dynastic imagery in early Timurid wall painting. Muqarnas,10, 253-265.

Mahir, B. (1993). Osmanlı saz üslubu resimlerinde ejder ikonografisi. Sanat tarihinde ikonografik araştırmalar: Güner İnal'a armağan (s. 271-294) içinde. Ankara: Hacettepe Üniversitesi Edebiyat Fakültesi.

Orkun, H. N. (1940). Prens Kalyanamkara ve Papamkara hikayesinin Uygurcası. Ankara: Türk Dil Kurumu Yayınlar1.

Ökten, S. (2002). Kâşî. İslam ansiklopedisi (25.Cilt) (s.15-16) içinde. İstanbul: Türkiye Diyanet Vakfi.Erişim adresi: https://islamansiklopedisi.org.tr/kasi

Öney, G. (1969) Anadolu selçuklu sanatında ejder figürleri. Belleten, 33(130), 171-192. Ankara: Türk Tarih Kurumu.

Özergin, M. K. (1976). Temürlü sanatına âit eski bir belge: Tebrizli, Ca’fer’in bir arzı. Sanat Tarihi Yıllı̆̆l, 6 , 471-518.

Russell, H. J. (2011). Iyi kötü prens öyküsü. V. Köken (Çev.). Ankara: Türk Dil Kurumu Yayınları.

Sayılı, A. (Ed.). (1991). Uluğ Bey ve Semerkand'deki ilim faaliyeti hakkında Glyâsuddin-i Kâş̂̀'nin mektubu. Ankara: Türk Tarih Kurumu.

Soucek, P. P. (1992). The manuscript of Iskender Sultan: Structure and content. Muqarnas, 6, 116-131.

Tanındı, Z. (1999). An illuminated manuscript of the wandering scholar Ibn al-Jazari and wandering illuminators between Tabriz, Shiraz, Herat, Bursa, Edirne, Istanbul in the 15th Century. Turkish art 10th international congress of Turkish art 1995 (s. 236-241) içinde. Geneve: Fondation Max van Berchem.

Tanındı, Z. (2009). Başlangıcından Osmanlı'ya tezhip sanatı. A. R. Özcan (Ed.), Hat ve tezhip sanatı (s. 243281) içinde. Ankara: Kültür Bakanlığı Yayınları.

Tekin, B. B. (2002). Timur dönemi ahşap kapıları. Türkler (8.Cilt) (s. 871-880) içinde. Ankara: Yeni Türkiye Yayınlar1.

Togan, Z. V. (1982). Ŏguz Destanı Reşideddin Ŏguznâmesi Tercüme ve Tahlili. İstanbul.

Valihocayev, B. (2003). Uluğ Bey devri medreseleri. K. Eshenkulova (Çev.). İstanbul: İSAR.

Yöndemli, F. (2006). Hayat ă̆acı ejder yılan. İstanbul: NKM.

\section{Görsel Kaynakçası}

Görsellerin bir kısmı resmi başvuru sonucunda künyeleri belirtilen kütüphanelerden alınmış, bir kısmı ise araştırmacı tarafından çekilmiştir. Çizimlerin tamamı Gülnihal Küpeli’ nin şahsi arşivine aittir.

Görsel 1. TSM. Hazine 2/1846, Uluğ Bey Sandı̆̆ (TSMK Arşivi, 2012).

Görsel 2. Üst kapakta yer alan ve sandığın Uluğ Bey için hazırlandığını gösteren yazı (TSMK Arşivi, 2012). 
Görsel 3. Üst kapak genel görünümü (TSMK Arşivi, 2012).

Görsel 4. Mesnevi, Nuruosmaniye Kütüphanesi 2559, v. 148b ( Süleymaniye Küt. Arşivi, 2012).

Görsel 5. Şirvanşahlar Sarayı Türbesi kapı alınlığı (1435-1436) İçeri Şehir, Bakü (G. Küpeli, 2012).

Görsel 6. Üst kapak, pervaz deseni (TSMK Arşivi; G. Küpeli, 2012).

Görsel 7. Üst kapak, 1/4 simetrik kompozisyon esasına göre tasarlanmış bezeme alanı (TSMK Arşivi; G. Küpeli, 2012).

Görsel 8. Üst kapak, 1/16 simetrik kompozisyon esasına göre tasarlanmış madalyon bezeme (TSMK Arşivi; G. Küpeli, 2012).

Görsel 9. Gûr-i Emir kubbesi ve kesitinin çizimi, Semerkand, 1400-1404 (G. Küpeli, 2012).

Görsel 10. Üst kapak, merkez madalyon içerisindeki ejder figürü ve çizimi (TSMK. Arşivi; G. Küpeli, 2012).

Görsel 11. Ejder figürünün ayağında yer alan çintemani motifi (G. Küpeli, 2012).

Görsel 12. TSMK. H.2152, vr. 97b, simurg ile mücadele eden ejder figürü ve ayağındaki çintemani detayı (TSMK Arşivi, 2019).

Görsel 13. Sandığın ön yüzü ve 1/4 desen analizi ( TSMK. Arşivi; G. Küpeli, 2012).

Görsel 14. Sandığın yan yüzü ve 1/4 desen analizi ( TSMK. Arşivi; G. Küpeli, 2012).

Görsel 15. Üst kapağın eğimli parçası ve deseni ( TSMK. Arşivi; G. Küpeli, 2012).

Görsel 16. Sandığın fildişi kakma bordürü ve desen ayrıntısı ( TSMK. Arşivi; G. Küpeli, 2012).

Görsel 17. İstanbul, Çinili köşk bordürleri (G. Küpeli, 2012).

Görsel 18. Sandığın içi ve ulama/raport tarzındaki ipek kumaşın desen analizi (TSMK. Arşivi; G. Küpeli, 2012). 